\title{
Acetoin Production in the Identification of Isolates as Members of Staphylococcus intermedius Hájek
}

\author{
N. BORNSTEIN AND J. FLEURETTE \\ Centre National de Référence des Staphylocoques, Laboratoire National de la Santé, Faculté de Médecine \\ Alexis Carrel, F-69372 Lyon Cedex, France
}

\begin{abstract}
A total of 50 staphylococcal strains of animal origin were identified as members of Staphylococcus intermedius Hájek on the basis that they possessed all of the characteristics originally reported by Hájek for $S$. intermedius except one, acetoin production. The Barritt method failed to demonstrate acetoin production by these isolates, whereas in the case of a micromethod in which pyruvate was used as substrate, acetoin production was detected. We discuss both the discrepancy observed between the results of the two methods and the taxonomic implications of our findings.
\end{abstract}

After studies on Staphylococcus aureus strains from animals, including humans, Hájek and Maršálek (10) suggested a six-biovar (biotype) classification for staphylococci (biovars A through F). Biovars $\mathrm{E}$ and $\mathrm{F}$ include strains isolated from dogs, horses, and mink (biovar $\mathrm{E}$ ), as well as from pigeons and foxes (biovar F), and differ from the other biovars in their biochemical and structural characteristics (11), thus positioning these biovars between $S$. aureus and the coagulase-negative staphylococci. Consequently, Hájek (9) advocated the recognition of a new species, Staphylococcus intermedius, for the strains of biovars $\mathbf{E}$ and $\mathrm{F}$.

Acetoin production was 1 of the 17 tests selected by Hájek (9) for species differentiation. To detect acetoin production, Hájek used two methods, the conventional technique of BairdParker (2) and the more rapid Davis-Hoyling test (6). Hájek found that $S$. intermedius did not produce acetoin.

In a study on coagulase-positive biovar $\mathrm{E}$ staphylococci of animal origin, we used two methods for the detection of acetoin, the conventional method of Baird-Parker (2), who utilized the Barritt method, and a micromethod (5). Our results did not agree with those of Hájek.

The purpose of this study was to draw attention to the problems that occur when attempts are made to use for taxonomic purposes characters whose determinations are based on the sensitivities of the methods employed.

\section{MATERIALS AND METHODS}

Bacterial strains. We studied 50 coagulase-positive Staphylococcus biotype E strains, which were identified by the criteria and methods described by Hájek and Maršálek $(9,11)$. Of these, 49 were from dogs and one was from poultry (Table 1). S. intermedius CCM 5739, $S$. aureus Cowan I (=NCTC 8530), and Staphylococcus epidermidis CCM 2124 were included as reference strains.

Methods. A total of 16 of the biochemical and morphological characters described by Hájek for $S$. intermedius were examined by the methods used by Hájek (9). These characters included the production of coagulase and thermonuclease, the anaerobic utilization of mannitol, the production of pigment, the susceptibility to phages of human origin, and the presence of $\alpha$ - and $\beta$-ribitol teichoic acids. Also, the presence of protein $A$ was investigated by two techniques, conditioned hemagglutination (8) and gel precipitation (14). Susceptibility to novobiocin was tested by using $30-\mu \mathrm{g}$ disks. Mannitol, maltose, mannose, and trehalose acidifications, nitrate reduction, and phosphatase production were examined by using a micromethod (5), the API Staph System (La Balme les Grottes, Montalieu Vercieu, France), and an 18-h culture prepared by the method of Brun et al. (5) as the inoculum. The production of acetoin was investigated by three methods. In the Barritt method (4), we used Clark and Lubs (Difco Laboratories, Detroit, Mich.) medium (glucose peptone medium buffered with dipotassium phosphate). In the Barritt method as modified by Abd-el-Malek and Gibson (1), we used glucose peptone medium without phosphate, and acetoin production was detected after incubation at $37^{\circ} \mathrm{C}$ for 2,7 , and 14 days. To $1 \mathrm{ml}$ of culture, $0.6 \mathrm{ml}$ of $6 \% \alpha$-naphthol in ethyl alcohol and $0.2 \mathrm{ml}$ of $40 \%$ potassium hydroxide (water solution) were added (2). And in the micromethod (5), sodium pyruvate was used as the substrate, and after $18 \mathrm{~h}$ of incubation acetoin production was detected by adding 1 drop each of $\alpha$-naphthol and $40 \%$ potassium hydroxide.

\section{RESULTS AND DISCUSSION}

In 14 of the 16 tests performed, the $S$. intermedius reference strain and our 50 strains produced the same results. However, these strains did not show two of the characteristics described 
TABLE 1. Strains of staphylococci used in this study

\begin{tabular}{|c|c|c|c|c|c|}
\hline \multirow{2}{*}{$\frac{\text { Serial no. }}{1}$} & \multirow{2}{*}{$\begin{array}{c}\begin{array}{c}\text { Laboratory } \\
\text { no. }\end{array} \\
791104\end{array}$} & \multicolumn{2}{|c|}{ Received as: } & \multirow{2}{*}{$\begin{array}{r}\text { Source } \\
\mathrm{CCM}^{\alpha}\end{array}$} & \multirow{2}{*}{$\begin{array}{c}\text { Habitat } \\
\begin{array}{c}\text { Nasal swabs from a } \\
\text { healthy pigeon }\end{array}\end{array}$} \\
\hline & & S. intermedius & CCM 5739 & & \\
\hline 2 & 800426 & S. aureus Cowan I & NCTC 8530 & CCM & Human \\
\hline 3 & 791103 & S. epidermidis & CCM 2124 & CCM & Human nose \\
\hline 4 & $\mathrm{SC1}$ & Staphylococcus sp. & & Pilet $^{b}$ & Canine \\
\hline 5 & SC2 & Staphylococcus sp. & & Pilet & Canine \\
\hline 6 & SC3 & Staphylococcus sp. & & Pilet & Canine \\
\hline 7 & SC4 & Staphylococcus sp. & & Pilet & Canine \\
\hline 8 & SC5 & Staphylococcus sp. & & Pilet & Canine \\
\hline 9 & SC6 & Staphylococcus sp. & & Pilet & Canine \\
\hline 10 & SC7 & Staphylococcus sp. & & Pilet & Canine \\
\hline 11 & SC8 & Staphylococcus sp. & & Pilet & Canine \\
\hline 12 & $323 \mathrm{C}$ & Staphylococcus sp. & & Devoyot $^{c}$ & Canine \\
\hline 13 & 21855 & Staphylococcus sp. & & Desmettre $^{d}$ & Canine \\
\hline 14 & 21723 & Staphylococcus sp. & & Desmettre & Canine \\
\hline 15 & 21890 & Staphylococcus sp. & & Desmettre & Canine \\
\hline 16 & 21684 & Staphylococcus sp. & & Desmettre & Canine \\
\hline 17 & 21714 & Staphylococcus sp. & & Desmettre & Canine \\
\hline 18 & 21644 & Staphylococcus sp. & & Desmettre & Canine \\
\hline 19 & 21869 & Staphylococcus sp. & & Desmettre & Canine \\
\hline 20 & 21861 & Staphylococcus sp. & & Desmettre & Canine \\
\hline 21 & 21762 & Staphylococcus sp. & & Desmettre & Canine \\
\hline 22 & 21740 & Staphylococcus sp. & & Desmettre & Canine \\
\hline 23 & 21807 & Staphylococcus sp. & & Desmettre & Canine \\
\hline 24 & 21734 & Staphylococcus sp. & & Desmettre & Canine \\
\hline 25 & 21875 & Staphylococcus sp. & & Desmettre & Canine \\
\hline 26 & 21834 & Staphylococcus sp. & & Desmettre & Canine \\
\hline 27 & 21800 & Staphylococcus sp. & & Desmettre & Canine \\
\hline 28 & 21679 & Staphylococcus sp. & & Desmettre & Canine \\
\hline 29 & 21853 & Staphylococcus sp. & & Desmettre & Canine \\
\hline 30 & 21687 & Staphylococcus sp. & & Desmettre & Canine \\
\hline 31 & 21851 & Staphylococcus sp. & & Desmettre & Canine \\
\hline 32 & 21667 & Staphylococcus sp. & & Desmettre & Canine \\
\hline 33 & 21704 & Staphylococcus sp. & & Desmettre & Canine \\
\hline 34 & 21735 & Staphylococcus sp. & & Desmettre & Canine \\
\hline 35 & 21761 & Staphylococcus sp. & & Desmettre & Canine \\
\hline 36 & 21768 & Staphylococcus sp. & & Desmettre & Canine \\
\hline 37 & 21774 & Staphylococcus sp. & & Desmettre & Canine \\
\hline 38 & 21808 & Staphylococcus sp. & & Desmettre & Canine \\
\hline 39 & 21833 & Staphylococcus sp. & & Desmettre & Canine \\
\hline 40 & 21839 & Staphylococcus sp. & & Desmettre & Canine \\
\hline 41 & 21876 & Staphylococcus sp. & & Desmettre & Canine \\
\hline 42 & 21889 & Staphylococcus sp. & & Desmettre & Canine \\
\hline 43 & 21891 & Staphylococcus sp. & & Desmettre & Canine \\
\hline 44 & 21893 & Staphylococcus sp. & & Desmettre & Canine \\
\hline 45 & 21681 & Staphylococcus sp. & & Desmettre & Canine \\
\hline 46 & 21707 & Staphylococcus sp. & & Desmettre & Canine \\
\hline 47 & 21710 & Staphylococcus sp. & & Desmettre & Canine \\
\hline 48 & 21718 & Staphylococcus sp. & & Desmettre & Canine \\
\hline 49 & 21760 & Staphylococcus sp. & & Desmettre & Canine \\
\hline 50 & 21826 & Staphylococcus sp. & & Desmettre & Canine \\
\hline 51 & 21843 & Staphylococcus sp. & & Desmettre & Canine \\
\hline 52 & 21884 & Staphylococcus sp. & & Desmettre & Canine \\
\hline 53 & 1547 & Staphylococcus sp. & & Desmettre & Poultry \\
\hline
\end{tabular}

${ }^{a}$ CCM, Czechoslovak Collection of Microorganisms, JE Purkyne University Trída Obráncú Miru, 1066243 Brno, Czechoslovakia.

${ }^{b}$ X. Pilet, Laboratory of Bacteriology, Veterinary School, Maisons Alfort, France.

${ }^{c} \mathrm{X}$. Devoyot, INRA, Aurillac, France.

${ }^{d} \mathrm{X}$. Desmettre, Laboratory of Bacteriology, IFFA Merieux, Lyon, France. 
by Hájek (Table 2); they acidified maltose and produced acetoin. With the Barritt method, acetoin production was detected in only two of our strains and was not detected in the reference strain. The presence of phosphate in the medium did not modify the result. In the two test strains that produced acetoin, the reaction was not detected until the day 7 , and the intensity increased between the days 7 and 14 (Table 3). With the micromethod, acetoin production was detected in all strains (Table 2).

The characteristics of our strains were in good agreement with those described by Hájek (9) for $S$. intermedius, and therefore our strains could be assigned to this species. As mentioned previously (17), the production of acid from maltose as determined by the micromethod did not agree with the results of Hajek, perhaps because phenol red was used as an indicator.

Routinely, acetoin production is determined for taxonomic and diagnostic purposes, especially in the Enterobacteriaceae. Within the Micrococcaceae, this character is useful in differentiating among Staphylococcus species (13). Baird-Parker (3) also used it to distinguish among the four biovars of $S$. epidermidis and

TABLE 2. Characters of 50 biovar $E$ staphylococcal test strains and three reference strains

\begin{tabular}{|c|c|c|c|c|}
\hline \multirow[b]{2}{*}{ Character } & \multirow[b]{2}{*}{$\begin{array}{l}\text { No. of } \\
\text { test } \\
\text { strains } \\
\text { giving } \\
\text { positive } \\
\text { reaction }\end{array}$} & \multicolumn{3}{|c|}{ Reaction of: } \\
\hline & & $\begin{array}{c}\text { S. inter- } \\
\text { medius } \\
\text { CCM } \\
5739\end{array}$ & $\begin{array}{c}\text { S. au- } \\
\text { reus } \\
\text { NCTC } \\
8530\end{array}$ & $\begin{array}{l}\text { S. epi- } \\
\text { dermi- } \\
\text { dis } \\
\text { CCM } \\
2124\end{array}$ \\
\hline $\begin{array}{l}\text { Acid from maltose } \\
\text { Acetoin production }\end{array}$ & 50 & + & + & + \\
\hline Barritt method & 2 & - & + & + \\
\hline $\begin{array}{l}\text { Barritt method } \\
\text { without phos- } \\
\text { phate }\end{array}$ & 2 & - & + & + \\
\hline Micromethod & 50 & + & + & + \\
\hline
\end{tabular}

among Staphylococcus saprophyticus strains. According to Hájek, it appears that $S$. intermedius is the only coagulase-positive Staphylococcus that does not produce acetoin; this fact induced Hájek (9) to select this character as the main criterion for differentiating $S$. intermedius from the other coagulase-positive staphylococci. Acetoin is produced from pyruvate in one of the metabolic pathways of glucose catabolism (20). When the enzymes of this pathway are present, the induction of these enzymes does not occur spontaneously but depends on cultural conditions $(7,20)$. Acetoin is not the only end product of glucose catabolism; when the oxidoreduction potential is low (for instance, in a glucose medium), acetoin is reduced to 2,3-butanediol, and when it is high (as in the presence of pyruvate), acetoin is oxidized to diacetyl (12). These reactions are reversible (18). The role of acetoin as a source of carbon has not been established (16). According to Barritt (4), acetoin can be detected by adding $\alpha$-naphthol and potassium hydroxide to a culture. A positive reaction is also obtained with diacetyl but not with 2,3-butanediol.

Therefore, the failure to detect acetoin production in an organism may be explained in the following ways: the organism does not possess a metabolic pathway for acetoin, the production of acetoin is not triggered because of cultural conditions, or acetoin and diacetyl are metabolized, in which case the acetoin reaction is positive at first and later becomes negative (19).

$S$. intermedius has a metabolic pathway for acetoin production, as demonstrated by the results which we obtained by using the micromethod and pyruvate as the substrate. Induction of this pathway by pyruvate seems to occur with staphylococci in general. Páčová and Kocur (15) have shown that production of acetoin by different bacterial species is more rapid when pyruvate rather than glucose is used as the substrate; moreover, acetoin production occurs more fre-

TABLE 3. Acetoin production by three staphylococcal strains as determined by three different methods

\begin{tabular}{|c|c|c|c|c|c|c|c|}
\hline \multirow{2}{*}{ Strain } & \multicolumn{3}{|c|}{$\begin{array}{l}\text { Acetoin production as deter- } \\
\text { mined by the Barritt method } \\
\text { after: }^{a}\end{array}$} & \multicolumn{3}{|c|}{$\begin{array}{l}\text { Acetoin production as deter- } \\
\text { mined by the Barritt method } \\
\text { without phosphate after: }{ }^{b}\end{array}$} & \multirow{2}{*}{$\begin{array}{c}\text { Acetoin } \\
\text { produc- } \\
\text { tion as } \\
\text { deter- } \\
\text { mined by } \\
\text { the mi- } \\
\text { cro- } \\
\text { method } \\
\text { after } 18 \mathrm{~h}\end{array}$} \\
\hline & $\stackrel{2}{\text { Days }}^{c}$ & 7 Days & 14 Days & 2 Days & 7 Days & 14 Days & \\
\hline S. intermedius 16 & - & + & +++ & - & ++ & +++ & ++ \\
\hline$S$. intermedius 45 & - & + & +++ & + & ++ & +++ & ++ \\
\hline S. aureus NCTC 8530 & - & + & + & - & + & ++ & ++ \\
\hline
\end{tabular}

${ }^{a}$ Clark and Lubs medium.

${ }^{b}$ Glucose peptone medium without phosphate.

${ }^{c}$ Incubation time. 
quently in staphylococci than in other organisms. Our observations confirm these findings (Tables 2 and 3 ).

It seems that the negative reactions obtained when the conventional method for detecting acetoin production was used were not due to the metabolism of acetoin and diacetyl because the positive reactions of two of the strains were enhanced with time (Table 3). Hájek used the following two methods for determining acetoin metabolism (9): the conventional technique of Baird-Parker (2), with glucose as the substrate (the same negative results were obtained as we obtained for our strains); and the Davis-Hoyling method (6), in which the substrate was pyruvate on a paper disk placed on the surface of a glucose agar plate for $3 \mathrm{~h}$ (the results of this test were also negative). In the micromethod described previously (5), the technique was quite different; the strain was grown for $18 \mathrm{~h}$ in an appropriate medium containing pyruvate as the specific substrate.

Hájek and Maršálek $(9,11)$ failed to demonstrate acetoin production in 90 to $100 \%$ of the biovar $\mathrm{E}$ staphylococcal strains tested by two methods (the conventional technique of BairdParker [2] and the more rapid Davis-Hoyling test [6]). This led them to advocate that this negative reaction should be used as a reliable taxonomic criterion for $S$. intermedius. Generally, negative test results are not conclusive, since it cannot be assumed that optimum experimental conditions were used to determine a given characteristc.

In the case of staphylococcal acetoin production, the micromethod in which pyruvate is used as the substrate seems to be the more sensitive method and thus is the preferred method.

\section{REPRINT REQUESTS}

Address reprint requests to: $\mathbf{N}$. Bornstein, Centre National de Référence des Staphylocoques, Laboratoire National de la Santé, Faculté de Médecine Alexis Carrel, Rue Guillaume Paradin, F-69372 Lyon Cedex 2, France.

\section{LITERATURE CITED}

1. Abd-el-Malek, Y., and T. Gibson. 1948. Studies in the bacteriology of milk. II. The staphylococci and micrococci of milk. J. Dairy Res. 15:249-260.

2. Baird-Parker, A. C. 1966. Methods for classifying staphylococci and micrococci, p. 59-64. In B. M. Gibbs and F. A. Skinner (ed.), Identification methods for micro- biologists, part A. Academic Press, Inc., New York.

3. Baird-Parker, A. C. 1974. Micrococcaceae, p. 478-490. In R. E. Buchanan and N. E. Gibbons (ed.), Bergey's manual of determinative bacteriology, 8 th ed. The Williams \& Wilkins Co., Baltimore.

4. Barritt, M. M. 1936. The intensification of the VogesProskauer reaction by the addition of $\alpha$-naphthol. J. Pathol. Bacteriol. 42:441-454.

5. Brun, Y., J. Fleurette, and F. Forey. 1978. Micromethod for biochemical identification of coagulase-negative staphylococci. J. Clin. Microbiol. 8:503-508.

6. Davis, G. H. G., and B. Hoyling. 1973. Use of a rapid acetoin test in the identification of staphylococci and micrococci. Int. J. Syst. Bacteriol. 23:281-282.

7. Eddy, B. P. 1961. The Voges Proskauer reaction and its significance: a review. J. Appl. Bacteriol. 24:27-41.

8. Flandrois, J. P., J. Fleurette, and F. Eyraud. 1975. Detection de la protéine A de Staphylococcus aureus par hémagglutination conditionnée. Ann. Biol. Clin. 33: 365-368.

9. Hájek, V. 1976. Staphylococcus intermedius, a new spe cies isolated from animals. Int. J. Syst. Bacteriol. 26: 401-408.

10. Hájek, V., and E. Maršálek. 1971. The differentiation of pathogenic staphylococci and a suggestion for their taxonomic classification. Zentralbl. Bakteriol. Parasitenkd. Infektionskr. Hyg. Abt. 1 Orig. Reihe A 217: 176182.

11. Hájek, V., and E. Maršálek. 1976. Evaluation of classificatory criteria for staphylococci, p. 11-21. In J. Jeljasjewicz (ed.), Staphylococci and staphylococcal diseases. Gustav Fisher Verlag, Stuttgart.

12. Happold, F. C., and C. P. Spencer. 1952. The enzymatic formation of acetyl-methylcarbinol and related compounds. Biochim. Biophys. Acta. 8:543.

13. Kocur, M. 1973. The taxonomy of the genus Staphylococcus, p. 5-12. In J. Jeljasjewicz (ed.), Staphylococci and staphylococcal infections. Polish Medical Publishers, Warsaw.

14. Oeding, P., and G. Haukenes. 1963. Identification of Staphylococcus aureus antigens and antibodies by means of the gel precipitation technique. Acta Pathol. Microbiol. Scand. 57:438-450.

15. Páčová, Z., and $M$. Kocur. 1973. A rapid microtest for the detection of acetoin. Zentralbl. Bakteriol. Parasitenkd. Infektionskr. Hyg. Abt. 1 Orig. Reihe A 223:106110.

16. Segal, B. 1940. The utilization of acetyl methylcarbinol by Staphylococcus albus and $S$. aureus. J. Bacteriol. 39: 747-749.

17. Shimizu, A., and E. Kato. 1979. Bacteriophage typing of Staphylococcus aureus isolated from dogs in Japan. Jpn. J. Vet. Sci. 41:405-408.

18. Strecker, H. J., and I: Harary. 1954. Bacterial butylene glycol deshydrogenase and diacetyl reductase. J. Biol. Chem. 211:263-270.

19. Tissler, R. P. 1938. The fermentation of acetyl methylcarbinol by the Escherichia, Aerobacter group and its significance in the Voges-Proskauer reaction. J. Bacteriol. 35: 157-162.

20. Watt, D., and C. H. Werkman. 1951. Modification of the enzyme system of Micrococcus pyogenes. Arch. Biochem. 31:383-390. 